\title{
STUDI BANDING ANTARA PROSES MORFO FONEMIK BAHASA INGGRIS DAN BAHASA INDONESIA
}

\author{
NURUL HIDAYATI \\ MTSN 16 Jombang \\ Email: nuruldani2017@gmail.com
}

\begin{abstract}
ABSTRAK
Tujuan dari penelitian ini adalah untuk membantu peserta didik untuk mengetahui dan memahami tentang : (1) Proses morfofonemik bahasa Inggris (2) proses morfofonemik bahasa Indonesia (3) perbedaan dan persamaan antara proses morfofonemik bahasa Inggris dan bahasa Indonesia. Metode yang digunakan dalam penelitian ini adalah deskriptif kualitatif. Metode deskriptif adalah metode yang menggambarkan dan menafsirkan tentang masalah yang diamati oleh peneliti. Kualitatif berarti menganalisis data dengan menggunakan pemikiran logis secara cermat untuk mendapatkan kesimpulan yang benar. Untuk memperoleh data penulis menggunakan dua sampel yaitu cerpen bahasa Inggris The End of The Party karya Graham Green dan cerpen bahasa Indonesia Kepala Kampung karya Emha Ainun Najib. Penulis menggunakan dua instrumen dalam pengumpulan data, yaitu studi kepustakaan dan dokumentasi. Penulis melibatkan mengidentifikasi, mendaftar dan mengklasifikasikan. Hasil penelitian menunjukkan bahwa terdapat beberapa persamaan dan perbedaan antara proses morfofonemik bahasa Inggris dan bahasa Indonesia. Berdasarkan dua sampel persamaan tersebut adalah asimilasi, penambahan dan eliminasi sedangkan aspek yang membedakannya lebih dari persamaannya yaitu perubahan vokal, pergeseran tekanan, sintesis dan supplesi.

Kata kunci : Studi banding, Morfo fonemik dalam Bahasa Inggris, Morfo fonemik dalam Bahasa Indonesia
\end{abstract}

\section{PENDAHULUAN}

Bahasa sangat penting bagi manusia karena tanpa bahasa mereka tidak dapat berkomunikasi dengan orang lain. Manusia tidak dapat dipisahkan dari bahasa. Mereka selalu berkomunikasi dengan orang lain dan melakukan sesuatu dengan menggunakan bahasa. Seperti yang dinyatakan Lim Kiat Boey dalam bukunya An Introduction Linguistics For Teachers "As human being, we all learn to speak at least one language which we hears we grow up unless we are ubnormal." (Boey, 1975:1) yang artinya "Sebagai manusia, kita semua belajar untuk berbicara setidaknya satu bahasa yang kita dengar ketika kita tumbuh kecuali kita tidak normal." (Boey, 1975:1). di sisi lain bahasa adalah sarana untuk bertukar informasi, berita, dan ide. Jadi, ada banyak definisi tentang bahasa.Salah satu definisi mengatakan bahwa "Language is an arbitrary system of articulated sounds made used of by a group of human as a mean of carrying on the affair of their society." (Francis, 1958:13) yang artinya "Bahasa adalah sistem arbitrer dari bunyi-bunyi artikulasi yang digunakan oleh sekelompok manusia sebagai alat untuk menjalankan urusan masyarakat mereka." (Fransiskus, 1958:13)

Linguistik adalah ilmu yang mempelajari tentang bahasa, sarana komunikasi yang paling berarti. Morfologi dan fonologi adalah subbidang linguistik. Mereka tidak dapat dipisahkan dalam proses morfofonemik. Proses morfo fonemik Bahasa Inggris dan Bahasa Indonesia keduanya berbeda. Oleh karena itu penulis memilih studi banding antara Proses morfo fonemik bahasa Inggris dan bahasa Indonesia sebagai topik.

Fonologi dan morfologi adalah subbidang linguistik. Morfo Fonemik digunakan untuk aspek umum dalam banyak bahasa. Seperti yang dinyatakan abdul Syukur dalam bukunya Model Linguistik Dewasa Ini bahwa "Istilah perubahan morfofonemik digunakan dalam kebanyakan bahasa dimana sebuah morfem menunjukkan pelafalan yang berbeda (distinc) tapi masih berkaitan didalam keadaan yang berbeda." (Ibrahim, 1987: 103). Baik fonologi maupun morfologi tidak dapat dipisahkan dalam proses morfo-fenimik sebagaimana dikemukakan Prof. 
Dr. Ramelan dalam bukunya English Phonetics bahwa Ketika kita mulai berbicara tentang morfo-fonemis kita telah memasuki ranah morfologi (Ramelan, 1985:166).

Penulis memilih fonologi dan morfologi sebagai topik karena beberapa alasan, pertama, baik fonologi dan morfologi berbeda antara bahasa Inggris dan bahasa Indonesia sehingga penulis ingin mengetahuinya. kedua fonologi dan morfologi tidak dapat dipisahkan dalam proses morfo fonemik. Seperti prof. Dr. ramelan menyatakan dalam bukunya fonetik bahasa Inggris bahwa " when we start talking about morpho phonemic we have entered the domain of morphology, which is beyond the treatment of phonemic and phonology" (Ramelan, 1985 : 166) yang artinya "ketika kita mulai berbicara tentang morfo fonemik, kita telah memasuki ranah morfologi, yang berada di luar perlakuan fonemik dan fonologi" (Ramelan, 1985: 166).

Ada 3 permasalahan yang penulis temukan : (1). Apa itu Morpho phonemic di dalam bahasa Inggris? (2). Apa itu Morfofonemik di dalam bahasa Indonesia? (3). Adakah perbedaan antara Morfo fonemik di dalam Bahasa Inggris dan Bahasa Indonesia? Dari ketiga masalah tersebut maka penulis tertarik untuk mengadakan penelitian ini.

\section{METODE PENELITIAN}

Metode yang digunakan dalam penelitian ini adalah deskriptif kualitatif. Metode deskriptif adalah metode yang menggambarkan dan menafsirkan tentang masalah yang diamati oleh peneliti. Kualitatif berarti menganalisis data dengan menggunakan pemikiran logis secara cermat untuk mendapatkan kesimpulan yang benar. Untuk memperoleh data penulis menggunakan dua sampel yaitu cerpen bahasa Inggris The End of The Party karya Graham Green dan cerpen bahasa Indonesia Kepala Kampung karya Emha Ainun Najib. Penulis menggunakan dua instrumen dalam pengumpulan data, yaitu studi kepustakaan dan dokumentasi. Penulis melibatkan mengidentifikasi, mendaftar dan mengklasifikasikan. Dalam pengumpulan data penulis menggunakan tehnik non statistik. Penulis membaca beberapa buku yang berhubungan dengan penelitian dan digunaksn untuk mendapatkan beberapa data. Dambil mbaca buku, penulis mencoba menganalisis jenis, perbedaan dan persamaan antara proses morfofonemik bahasa Inggris dan Bahada Indonesia.

\section{HASIL DAN PEMBAHASAN}

Penelitian yang dilakukan peneliti pada proses morfofonemik Inggris dan Indonesia menggunakan dua cerita pendek sebagai subjeknya. Data atau klasifikasi yang dihasilkan akan disajikan dalam bab ini.

\section{A. Analisis Prose Morfofonemik Bahasa Inggris}

\section{Analisis Asimilasi.}

Analisis ini digunakan untuk mengetahui proses asimilasi morfofonemik yang digunakan dalam cerpen The End Of The Party.

Tabel 1. klasifikasi yang dihasilkan dari proses asimilasi The End Of The Party

\begin{tabular}{|l|l|l|}
\hline Morfem & Morfem & Hasil kombinasi \\
\hline -in & patient & impatient \\
\hline -in & perfect & imperfect \\
\hline look & -ed & looked \\
\hline ask & -ed & asked \\
\hline cheek & -s & cheeks \\
\hline
\end{tabular}

Berdasarkan sampel, analisis akan menunjukkan bagaimana proses asimilasi terbentuk.

a. "IMPATIENT' terbentuk dari "in" + "patient", ada perubahan dari bunyi /in/ menjadi /im/. Berdasarkan jenis asimilasi, proses ini disebut asimilasi regresif karena bunyi bilabial /p/. 
b. "IMPERFECT'terbentuk dari "in" + "perfect", ada perubahan dari bunyi /in/ menjadi /im/. Berdasarkan jenis asimilasi, proses ini disebut asimilasi regresif karena bunyi bilabial /p/.

c. "LOOKED” terbentuk dari "look" + "ed" menjadi /lukt/, ada perubahan dari bunyi /d/ (bentuk masa lampau) menjadi bunyi/t/.Berdasarkan jenis asimilasi, proses ini disebut asimilasi suara karena bentuk lampau /d/ ditambahkan ke kata kerja yang mengakhiri penghentian alveolar tanpa suara /t/.

d. "ASKED" " terbentuk dari "ask" + "ed" menjadi /askt/, ada perubahan dari bunyi /d/ (bentuk masa lampau) menjadi bunyi/t/.Berdasarkan jenis asimilasi, proses ini disebut asimilasi suara karena bentuk lampau /d/ ditambahkan ke kata kerja yang berakhiran konsonan tak bersuara, diganti dengan penghentian alveolar tanpa suara /t/.

e. "CHEEKS" terbentuk dari "cheek" + "s" /z/ menjadi /tfi:ks/, ada perubahan dari bunyi /z/ bentuk jamakmenjadi bunyi/s/.Berdasarkan jenis asimilasi, proses ini disebut asimilasi suara karena /z/ bentuk jamak ditambahkan ke kata benda yang berakhiran frikatif bersuara /s/.

\section{Analisis Elision atau Hilangnya Suara}

Analisis ini digunakan untuk mengetahui proses elision atau hilangnya suara morfofonemik yang digunakan dalam cerpen The End Of The Party.

Tabel 2. Klasifikasi yang dihasilkan dari proses elision atau hilangnya suaraThe End Of The Party

\begin{tabular}{|l|l|l|}
\hline morfem & morfem & Hasil kombinasi \\
\hline don't & you & don't you \\
\hline and & then & and then \\
\hline must & go & must go \\
\hline and & tap & and tap \\
\hline last & resort & last resort \\
\hline last & year & last year \\
\hline
\end{tabular}

Berdasarkan sampel, analisis akan menunjukkan bagaimana proses elision atau hilangnya suara terbentuk.

a. "DON"T YOU" terbentuk dari "don't" /dont/ + "you" /zu/ menjadi /donzu/, ada perubahan dari bunyi /t/ dari "don't" hilang.

b. "AND THEN' terbentuk dari "and"/ænd/ + "then"/ðen/ menjadi /ænðen /, ada perubahan dari bunyi /d/ dari "and" hilang.

c. "MUST GO" terbentuk dari "must" /mıst/ + "go" /gou/ menjadi /məsgou /, ada perubahan dari bunyi /t/ dari "must" hilang.

d. "AND TAP" " terbentuk dari "and" / ænd / + "tap" /tæp/ menjadi /æntæp /, ada perubahan dari bunyi /d/ dari "and" hilang.

e. "LAST RESORT" terbentuk dari "last" / lp:st / + "resort" /rIzət/ menjadi /lp:s rIzət /,ada perubahan dari bunyi /t/ dari "last" hilang.

f. "LAST YEAR" terbentuk dari "last" / lp:st / + "year" /je:(r)/ menjadi /lp:s je:(r) /, ada perubahan dari bunyi /t/ dari "last" hilang.

\section{Analisis addition (penambahan).}

Analisis ini digunakan untuk mengetahui proses addition (penambahan) morfofonemik yang digunakan dalam cerpen The End Of The Party.

Tabel 3. Klasifikasi yang dihasilkan dari proses addition (penambahan) The End Of The Party

\begin{tabular}{|l|l|l|}
\hline morfem & morfem & Hasil kombinasi \\
\hline need & n't & needn't \\
\hline ought & n't & oughtn't \\
\hline had & n't & hadn't \\
\hline
\end{tabular}


Berdasarkan sampel, analisis akan menunjukkan bagaimana proses addition (penambahan) terbentuk.

a. "NEEDN'T" terbentuk dari "need" + "n't" menjadi /ni:dənt/, ada penambahan bunyi /yaitu bunyi /a/ setelah bunyi /d/ d ari "need".

b. "OUGHN'T" terbentuk dari "ought" + "n't" menjadi / :tənt/, ada penambahan bunyi /yaitu bunyi /o/ setelah bunyi /t/ d ari "ought".

c. "HADN'T" terbentuk dari "had" + "n't" menjadi /hædənt/, ada penambahan bunyi /yaitu bunyi /ə/ setelah bunyi /d/ d ari "had".

\section{Analisis vowel change (perubahan vokal).}

Analisis ini digunakan untuk mengetahui proses vowel change (perubahan vocal) morfofonemik yang digunakan dalam cerpen The End Of The Party.

Tabel 4. Klasifikasi yang dihasilkan dari proses vowel change (perubahan vokal) The End Of The Party

\begin{tabular}{|l|l|l|}
\hline morfem & morfem & hasil kombinasi \\
\hline desperate & ion & desperation \\
\hline invite & ation & invitation \\
\hline child & ren & children \\
\hline
\end{tabular}

Berdasarkan sampel, analisis akan menunjukkan bagaimana proses vowel change (perubahan vokal) terbentuk.

a. "DESPERATION" terbentuk dari "desparate" /desporit/ + "ion" /yən/ menjadi /despəreisyen/, ada perubahan vokal /yaitu bunyi vocal/i/ dari /despərit/ menjadivocal /ei/.

b. "INVITATION" terbentuk dari "invite" /invait/ + "ation" /æ $\mathrm{fn} / \mathrm{menjadi} /$ inviteifn/, ada perubahan vokal /yaitu bunyi vocal /ai/ dari /invait/ menjadivocal /i/ dan /æ/ dari /æx $\mathrm{n} /$ menjadi /ei/.

c. "CCHILDREN" terbentuk dari "child"/tfaIld/ + "ren" /bentuk jamak/ menjadi /t filldrən/, ada perubahan vokal /yaitu bunyi vocal /aI/ dari /tfalld / menjadi vocal /I/ .

\section{Analisis shift of stress (pergeseran penekanan).}

Analisis ini digunakan untuk mengetahui proses shift of stress (pergeseran penekanan) morfofonemik yang digunakan dalam cerpen The End Of The Party.

Tabel 5. Klasifikasi yang dihasilkan dari proses shift of stress (pergeseran penekanan) The End Of The Party

\begin{tabular}{|l|l|l|}
\hline morfem & morfem & hasil kombinasi \\
\hline desperate & ion & desperation \\
\hline invite & ation & invitation \\
\hline
\end{tabular}

Berdasarkan sampel, analisis akan menunjukkan bagaimana proses shift of stress (pergeseran penekanan) terbentuk.

a. "DESPERATION" terbentuk dari "desparate"+ "ion", penekanan "desparate" berbeda dari "desperation"karena ada penambahan "ion".

b. "INVITATION" terbentuk dari "invite" + "ation" , penekanan "invite" berbeda dari "invitation"karena ada penambahan "ion".

\section{Analisis synthesis (sintesis)}


Analisis ini digunakan untuk mengetahui proses sintesis morfofonemik yang digunakan dalam cerpen The End Of The Party.

Tabel 6. Klasifikasi yang dihasilkan dari proses sintesis The End Of The Party

\begin{tabular}{|l|l|l|}
\hline morfem & morfem & hasil kombinasi \\
\hline direct & ion & direction \\
\hline desperate & ion & desperation \\
\hline suggest & ion & suggestion \\
\hline protect & ion & protection \\
\hline
\end{tabular}

Berdasarkan sampel, analisis akan menunjukkan bagaimana proses sintesisterbentuk.

a. "DIRECTION" terbentuk dari "direct" /dIrekt/ + "ion" /yən/ menjadi /dIrektsyən/, penggabungan dari fonem /t/ dari "direct" dan fonem /y/ dari "ion" menjadi /sy/ di "direction".

b. "DESPERATION" terbentuk dari "desparate" + "ion",/despərit/ + /yən/ menjadi/despəreisyən/, penggabungan dari fonem /t/ dari "desparate" dan fonem /y/ dari "ion" menjadi /sy/ di "desperation".

c. "SUGGESTION" terbentuk dari "suggest" + "ion",/səgjest/ + /yən/ menjadi

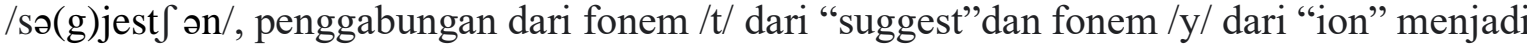
fonem /t $\mathrm{t} /$ dalam bahasa indonesia dibaca /c/ di "suggestion".

\section{Analisis suppletion (suplesi)}

Analisis ini digunakan untuk mengetahui proses suplesimorfofonemik yang digunakan dalam cerpen The End Of The Party.

Tabel 7. Klasifikasi yang dihasilkan dari proses suppletion (suplesi) The End Of The Party

\begin{tabular}{|l|l|l|}
\hline morfem & morfem & hasil kombinasi \\
\hline bad & $\begin{array}{l}\text { perbandingan } \\
\text { tingkat lebih }\end{array}$ & worse \\
\hline go & bentuk lampau & went \\
\hline child & bentuk jamak & children \\
\hline
\end{tabular}
terbentuk.

Berdasarkan sampel, analisis akan menunjukkan bagaimana proses suppletion (suplesi) a. "WORSE" terbentuk dari "bad" + " perbandingan tingkat lebih" , kata "worse" sangat berbeda dari kata "bad".

b. "WENT" terbentuk dari "go" + " bentuk lampau", kata "went" sangat berbeda dari kata "go".

c. "CHILDREN" terbentuk dari "child" + "ren" (bentuk jamak), bentuk jamak /rən/ sangat berbeda dari bentuk jamak /z/ bentuk dasar dari morfem jamak.

\section{B. Analisis Proses Morfofonemik Bahasa Indonesia.}

\section{Analisis Perubahan Fonem.}

Analisis ini digunakan untuk mengetahui proses perubahan fonem morfofonemik yang digunakan dalam cerpenKepala Kampung. 
Tabel 8. Klasifikasi yang dihasilkan dari proses perubahan fonem Kepala Kampung

\begin{tabular}{|l|l|l|}
\hline morfem & morfem & hasil kombinasi \\
\hline me(N)- & bikin & membikin \\
\hline me(N)- & cium & mencium \\
\hline me(N)- & genggam & menggenggam \\
\hline me(N)- & pegang & memegang \\
\hline me(N)- & sambut & menyambut \\
\hline me(N)- & angkat & memupuk \\
\hline me(N)- $\quad$ kan & tentu & mengangkat \\
\hline me(N)- kan & temu & menentukan \\
\hline me(N)- kan & hasil & menemukan \\
\hline me(N)- kan & cermin & menghasilkan \\
\hline me(N)- kan & putus & mencerminkan \\
\hline me(N)- kan & jengkel & memutuskan \\
\hline me(N)- kan & bukti & menjengkelkan \\
\hline me(N)- kan & bungkuk & membuktikan \\
\hline me(N)- kan & pancar & membungkukkan \\
\hline me(N)- i & duduk & memancarkan \\
\hline me(N)- i & hadap & menduduki \\
\hline me(N)- i & jejal & menghadapi \\
\hline pe(N)- an & bagi & pembagian \\
\hline pe(N)- an & pikir & pemikiran \\
\hline pe(N)- an & korban & pengorbanan \\
\hline pe(N)- an & tatar & penataran \\
\hline pe(N)- an & bakar & pembakaran \\
\hline pe(N)- an & abdi & pengabdian \\
\hline ber- & ajar & belajar \\
\hline
\end{tabular}

Berdasarkan sampel, analisis akan menunjukkan bagaimana proses perubahan fonem terbentuk.

a. "MEMBIKIN', "MEMBUKTIKAN", "MEMBUNGKUKKAN", "PEMBAGIAN" DAN "PEMBAKARAN" terbentuk dari "me(N)-kan + bikin", "me(N)-kan + bukti", "me(N)kan +bungkuk", "pe(N)-an + bagi", "pe(N)- an + bakar. Fonem /N/ dari me(N) dan pe(N) berubah menjadi /m/ karena dikuti oleh kata dasar yang memiliki fonem pertama /b/.

b. "MENCIUM" dan "MENCERMINKAN" terbentuk dari "me(N)- + cium" dan "me(N)-kan + cermin" fonem /N/ dari me(N)- berubah menjadi / ̌̌/ karena dikuti oleh kata dasar yang memiliki fonem pertama /c/.

c. "MEMEGANG", "MEMUTUSKAN","MEMUPUK', "MEMANCARKAN" dan"PEMIKIRAN" terbentuk dari kata "me(N) + pegang", "me(N) + putus", "me(N) + pupuk" "me(N)-kan + pancar","me $(\mathrm{N})-$ an + pikir".Fonem $/ \mathrm{N} /$ dari me $(\mathrm{N})$ dan pe $(\mathrm{N})$ berubah menjadi $/ \mathrm{m} /$ karena dikuti oleh kata dasar yang memiliki fonem pertama $/ \mathrm{p} /$.

d. "MENGHASILKAN" terbentuk dari "me(N)-kan + hasil. Fonem /N/ dari me(N) ) berubah menjadi /y/ karena dikuti oleh kata dasar yang memiliki fonem pertama $/ \mathrm{h} /$.

e. "MENGHADAPI" terbentuk dari "me(N)- i + hadap".Fonem /N/ dari me(N) ) berubah menjadi /y/ karena dikuti oleh kata dasar yang memiliki fonem pertama /h/.

f. "MENJENGKELKAN" dan "MENJEJALI" terbentuk dari "me(N)-kan +jengkel" dan "me(N)- i + jejal". Fonem /N/ dari me(N) berubah menjadi /ň/ karena dikuti oleh kata dasar yang memiliki fonem pertama $/ \mathrm{j} /$. 
g. "MENGGENGGAM" terbentuk dari "me(N)- +genggam". Fonem /N/ dari me(N) ) berubah menjadi /y/ karena dikuti oleh kata dasar yang memiliki fonem pertama /g/.

h. "MENYAMBUT" terbentuk dari "me(N)- + sambut". Fonem /N/ dari me(N) ) berubah menjadi /n̆/ karena dikuti oleh kata dasar yang memiliki fonem pertama /s/.

i."MENENTUKAN","MENEMUKAN",dan "PENATARAN" terbentuk dari k"me(N)-kan +tentu" "me(N)-kan +temu", "pe(N)-an +tatar"Fonem $/ \mathrm{N} /$ dari me $(\mathrm{N})$ dan pe(N) berubah menjadi /n/ karena dikuti oleh kata dasar yang memiliki fonem pertama /t/.

j. "PENGORBANAN" terbentuk dari "pe(N)-an + kurban". Fonem /N/ dari pe(N) berubah menjadi /y/ karena dikuti oleh kata dasar yang memiliki fonem pertama $/ \mathrm{k} /$.

k. "PENGABDIAN" terbentuk dari "pe(N)-an + abdi". Fonem /N/ dari pe(N) berubah menjadi $/ \mathrm{y} /$ karena dikuti oleh kata dasar yang memiliki fonem vokal /a/.

1. "BELAJAR" terbentuk dari "ber- + ajar". Fonem /r/ dari ber- berubah menjadi /1/ karena dikuti oleh kata dasar yang memiliki fonem vokal /a/.

\section{Analalisis Penambahan Fonem.}

Analisis ini digunakan untuk mengetahui proses penambahan fonem morfofonemik yang digunakan dalam cerpen Kepala Kampung.

Tabel 9. Klasifikasi yang dihasilkan dari proses penambahan fonem Kepala Kampung

\begin{tabular}{|l|l|l|}
\hline morfem & morfem & hasil kombinasi \\
\hline -an & ribu & ribuan \\
\hline ke-an & kaya & kekayaan \\
\hline ke-an & curiga & kecurigaan \\
\hline ke-an & bijaksana & kebijaksanaan \\
\hline ke-an & maju & kemajuan \\
\hline per -an & satu & persatuan \\
\hline pe(N) -an & bagi & pembagian \\
\hline pe(N) - an & abdi & pengabdian \\
\hline ke-an & tidak mengerti & ketidakmengertian \\
\hline per - an & kerja & pekerjaan \\
\hline
\end{tabular}

Berdasarkan sampel, analisis akan menunjukkan bagaimana proses penambahan fonem terbentuk.

a. "RIBUAN"terbentuk dari "-an" + "ribu" menjadi /ribuwan/ ada penambahan fonem /w/ setelah fonem /u/ dari "ribu".

b. "KEKAYAAN" terbentuk dari "ke-an" + "kaya" menjadi /kekaya'an / ada penambahan fonem /'/ setelah fonem /a/ dari "kaya".

c. "KECURIGAAN" terbentuk dari "ke-an" + "curiga " menjadi /kecuriga'an / ada penambahan fonem /'/ setelah fonem /a/ dari "curiga".

d. "KEBIJAKSANAAN" terbentuk dari "ke-an" + "bijaksana" menjadi /kebijaksana'an/ ada penambahan fonem /'/ setelah fonem /a/ dari "bijaksana".

e. "KEMAJUAN" terbentuk dari "ke-an" + "maju" menjadi /kemajuwan/ ada penambahan fonem /w/ setelah fonem /u/ dari "maju".

f. "PERSATUAN" terbentuk dari "per-an" + "satu" menjadi /persatuwan/ ada penambahan fonem /w/ setelah fonem /u/ dari "maju".

g." PEMBAGIAN" terbentuk dari "pe(N)-an" + "bagi" menjadi / pembagiyan / ada penambahan fonem /y/ setelah fonem /i/ dari "bagi".

h."KETIDAKMENGERTIAN" " terbentuk dari "ke-an" + "tidak mengerti" menjadi

/ketidakmengertian/ ada penambahan fonem /w/ setelah fonem /u/ dari "maju".

i. "PEKERJAAN" terbentuk dari "pe-an" + "kerja" menjadi /pekerja'an/ ada penambahan fonem /'/ setelah fonem /a/ dari "kerja". 


\section{Analisis Penghilangan Fonem}

Analisis ini digunakan untuk mengetahui proses penambahan fonem morfofonemik yang digunakan dalam cerpenKepala Kampung.

Tabel 10. Klasifikasi yang dihasilkan dari proses penghilangan fonem

\section{Kepala Kampung}

\begin{tabular}{|l|l|l|}
\hline morfem & morfem & hasil kombinasi \\
\hline me(N)- kan & rencana & merencanakan \\
\hline me(N)- & rasa & merasa \\
\hline me(N)- kan & rugi & merugikan \\
\hline me(N)- & lihat & melihat \\
\hline me(N)- kan & laksana & melaksanakan \\
\hline per -an & kerja & pekerjaan \\
\hline
\end{tabular}

Berdasarkan sampel, analisis akan menunjukkan bagaimana proses penghilangan fonem terbentuk.

a. "MERENCANAKAN" terbentuk dari "me(N)-kan" +"rencana". Fonem /N/ dari me(N) dihilangkan atau mengalami penghilangan fonem /N/.

b. "MERASA" terbentuk dari "me(N)-“" " "rasa". Fonem /N/ dari me(N) dihilangkan atau mengalami penghilangan fonem /N/.

c. "MERUGIKAN" terbentuk dari "me(N)-kan" +"rugi". Fonem /N/ dari me(N) dihilangkan atau mengalami penghilangan fonem $/ \mathrm{N} /$.

d. "MELIHAT" terbentuk dari "me(N)-“ + "lihat". Fonem /N/ dari me(N) dihilangkan atau mengalami penghilangan fonem $/ \mathrm{N} /$.

e. "MELAKSANAKAN" terbentuk dari "me(N)-kan" +"laksana". Fonem /N/ dari me(N) dihilangkan atau mengalami penghilangan fonem /N/.

f. "PEKERJAAN" terbentuk dari "per-an" + "kerja".Fonem /r/ dari per-dihilangkan atau mengalami penghilangan fonem $/ \mathrm{r} /$.

\section{Persamaan Antara Morfo fonemik Bahasa Inggris dan Bahasa Indonesia.}

Setelah melakukan analisis yang disajikan dari hasil analisis data persamaan, beberapa aspek yang berhubungan dengan analisis adalah sebagai berikut:

\section{Assimilation atau perubahan fonem.}

\begin{tabular}{|l|l|}
\hline Bahasa Inggris & Bahasa Indonesia \\
\hline$\underline{\text { Morfem + morfem }}$ & Morfem + morfem \\
\hline in- perfect ; imperfect & me(N)- bikin ; membikin \\
in- patient ; impatient & me(N)- bagi ; membagi \\
-s /z/ cheek ; cheeks & ber- ajar ; belajar \\
ed /d/ ask ; asked /askt/ & me(N)- sambut ; menyambut \\
\hline
\end{tabular}

2.Addition atau penambahan fonem.

\begin{tabular}{|c|c|c|c|}
\hline Bahasa I & & \multicolumn{2}{|c|}{ Bahasa Indonesia } \\
\hline Morfem & em & Morfem + & fem \\
\hline $\begin{array}{l}\text { n't } \\
\text { n'tought } \\
\text { n't }\end{array}$ & $\begin{array}{l}\text { need; needn't } \\
\text {; oughtn't } \\
\text { had; hadn't }\end{array}$ & $\begin{array}{l}\mathrm{Ke}-\text { an } \\
- \text { an } \\
\mathrm{Pe}(\mathrm{N})-\text { an }\end{array}$ & $\begin{array}{l}\text { kaya ; kekayaan } \\
\text { ribu ; ribuan } \\
\text { bagi ; pembagian }\end{array}$ \\
\hline
\end{tabular}


3. Elision atau penghilangan fonem.

\begin{tabular}{|l|l|}
\hline Bahasa Inggris & Bahasa Indonesia \\
\hline Morfem + morfem & Morfem + morfem \\
\hline $\begin{array}{l}\text { Must go;must go } \\
\text { /mıst//gou//məsgou / } \\
\text { last resort; last resort } \\
\text { / lp:st / /rIzət//lp:s rIzət / } \\
\begin{array}{l}\text { don't you ; don't you } \\
\text { /dont/ /zu/ /donzu/ }\end{array}\end{array}$ & me(N)- lihat \\
\hline
\end{tabular}

\section{Perbedaan antara morfo fonemik Bahasa Inggris dan Bahasa Indonesia.}

Setelah melakukan analisis yang disajikan dari hasil analisis data perbedaan, beberapa aspek yang berhubungan dengan analisis adalah sebagai berikut:

1. Vowel change.

\begin{tabular}{|l|l|}
\hline Bahasa Inggris & Bahasa Indonesia \\
\hline Morfem + morfem & Morfem + morfem \\
\hline -ion desperate ; desperation & - \\
-ion invite ; invitation & - \\
-ren child ; children & - \\
\hline
\end{tabular}

2. Shift of stress.

\begin{tabular}{|l|l|}
\hline Bahasa Inggris & Bahasa Indonesia \\
\hline Morfem + morfem & Morfem + morfem \\
\hline $\begin{array}{l}\text {-ion desperate ; desperation } \\
\text {-ion invite ; invitation }\end{array}$ & - \\
& - \\
\hline
\end{tabular}

3. Synthesis.

\begin{tabular}{|c|c|}
\hline Bahasa Inggris & Bahasa Indonesia \\
\hline Morfem + morfem & Morfem + morfem \\
\hline 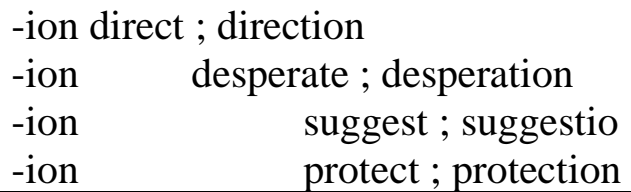 & $\begin{array}{l}- \\
- \\
- \\
-\end{array}$ \\
\hline
\end{tabular}

4. Suppletion.

\begin{tabular}{|l|l|}
\hline \multicolumn{1}{|c|}{ Bahasa Inggris } & Bahasa Indonesia \\
\hline Morfem + morfem & Morfem + morfem \\
\hline Bad /comparative/ ; worse & - \\
Go /past form/; went & - \\
child /plural/ ; children & - \\
\hline
\end{tabular}

\section{KESIMPULAN}

Berdasarkan analisa data, penulis membuat kesimpulan bahwa dalam beberapa aspek terdapat beberapa perbedaan dan persamaan antara proses morfofonemik bahasa Inggris dan bahasa Indonesia. Aspek yang membuat terbentuknya morfofonemik dalam dua bahasa tersebut dapat digambarkan sebagai berikut:

1. Proses morfofonemic Assimilasi Bahasa Inggris dan Bahasa Indonesia.

Contoh: in + perfect

$$
\begin{aligned}
& \text { s /z/ + cheek } \\
& \text { ber- + ajar }
\end{aligned}
$$

imperfect

cheeks

belajar 


$$
\text { me }(\mathrm{N})+\text { pegang }
$$

memegang

Walaupun terdapat beberapa perbedaan pada kaidah atau proses itu sendiri, pada umumnya cara dasarnya sama yaitu asimilasi atau perubahan fonem adalah proses morfofonemik yang umum pada kedua bahasa tersebut.

2. Proses morfofonemik bahasa Inggris dan bahasa Indonesia memiliki cara yang sama berdasarkan proses Addition atau penambahan fonem.
Contoh : need + n't
needn't /ni:dənt/
ought + n't
oughtn't /o:tənt/
had + n't hadn't/hædənt/
ribu + an ribuan /ribuwan/
per - an + satu
pe $(\mathrm{N})+$ bagi

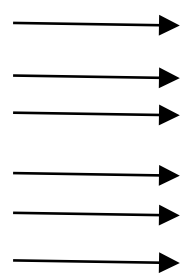
persatuan /persatuwan/
pembagian /pembagiyan/

Meskipun terdapat banyak perbedaan pada kaidah atau proses itu sendiri, pada umumnya cara dasarnya sama yaitu addition atau penambahan fonem merupakan proses morfofonemik yang umum pada kedua bahasa tersebut.

3. Baik proses morfo-fonemis bahasa Inggris maupun bahasa Indonesia memiliki cara yang sama dalam proses elision atau penghilangan fonem.
Contoh: Must + go
must go
/must//gou/ /məsgou /
last + year
/ lp:st / /je:(r)/

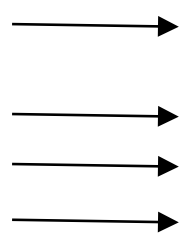
last year
$/ \mathrm{lp}: \mathrm{s} \mathrm{j} \varepsilon:(\mathrm{r})$
Per-an + kerja
$\mathrm{Me}(\mathrm{N})+$ lihat
pekerjaan
melihat
$\mathrm{Me}(\mathrm{N})+$ rasa
merasa

Meskipun terdapat banyak perbedaan pada kaidah atau proses itu sendiri, pada umumnya cara dasarnya sama yaitu elision atau penghilangan fonem merupakan proses morfofonemik yang umum pada kedua bahasa tersebut.sedangkan aspek perbedaan antara morfofonemik bahasa inggris dan bahasa indonesia adalah sebagai berikut:

1. Proses morfofonemik bahasa Inggris adalah penggabungan satu morfem menjadi morfem yang lain dan mengalami perubahan fonem. Semua morfem dapat mengalami morphophonemic dalam bahasa Inggris. Di sisi lain, morfem yang umum digunakan dalam bahasa Indonesia adalah bentuk dasar, akhiran, dan awalan.

Dalam bahasa Inggris juga terdapat morfem jamak, bentuk lampau dan morfem komparatif (perbadingan)yang dapat membuat proses morfo-fonemik.

Contoh: cheek $+\mathrm{s} / \mathrm{z} /$

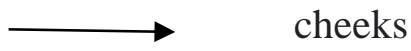

ask + ed /d/

bad + comparative

asked /askt/

worse

Tetapi dalam bahasa Indonesia hanya imbuhan yang membuat proses morfofonemik.

Contoh : $\operatorname{me}(\mathrm{N})+$ pegang

-an + ribu

per - an + kerja

pe $(\mathrm{N})-$ an + korban

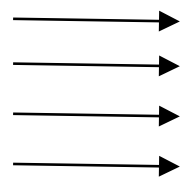

memegang

ribuan

pekerjaan

pengorbanan

2. Vowel change.

Morfofonemik ini ada dalam bahasa Inggris dan sering kita jumpai di buku-buku bahasa Inggris. Di sisi lain sangat jarang dalam bahasa Indonesia atau penulis mengatakan mungkin tidak ada dalam bahasa Indonesia.

Contoh: invite + ion

/invait/

child + ren

/t faild/

desperate + ion

/despərit/ invitation

/inviteisyen/

children

/tfildren/

desperat ion

/despəreisyən/ 
Tidak ada proses vowel change dalam morfofonemik bahasa Indonesia.

3. Shift of stress.

Proses morfofonemik ini ada dalam Bahasa Inggris, biasanya sebagai hasil atau perubahan kualitas vokal. di sisi lain proses morfofonemik ini tidak ada dalam bahasa Indonesia.

Contoh : désperate + ion

in'vite + ion

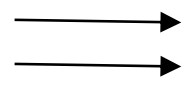
desperátion invi'tation

\section{Synthesis}

Morfofonemik ini ada dalam bahasa Inggris dan sering kita jumpai di buku-buku bahasa Inggris, tapi tidak ditemukan dalam Bahasa Indonesia.Disebut sintesis ketika dua suara milik morfem yang berbeda dapat menyatu atau mensintesis menjadi satu sama lain dan menjadi suara baru, yang berbeda dari dua suara asli.

Contoh : direct + ion

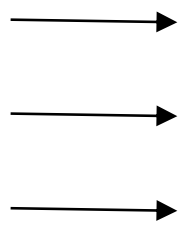

direction

/dIrekt/ /yən/

suggest + ion

/səgjest//yən/

desperate + ion

/dIrektsyən/

suggestion

/sə(g)jest $\int$ ən/

desperat ion

/despərit//yən/

/despəreisyən/

\section{Suppletion.}

Morfofonemik ini ada dalam bahasa Inggris dan sering kita jumpai di buku-buku bahasa Inggris, tapi tidak ditemukan dalam Bahasa Indonesia.

Contoh: Bad + /comparative

Go + /past form

Child + /plural

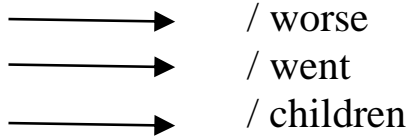

\section{DAFTAR PUSTAKA}

Akmajian A, Damers A, Robert, Harnish M.(1984). An Introduction to Language and Communication. London : University on Arizona.

Alwasilah. (1987). Linguistik Suatu Pengantar. Bandung : Angkasa Bandung.

Balai Pustaka. (1982). Pedoman Umum Bahasa IndonesiaYang Disempurnakan. Jakarta : Departemen Pendidikan dan Kebudayaan

Balai Pustaka. (1993). Tata Bahasa Baku Bahasa Indonesia. Jakarta : Departemen Pendidikan dan Kebudayaan.

Bloomfield, Leonard. (1984). Language. New York : Hold Rinehart and Winston Inc.

Carrol, John B. (1959). The Study Of Language. Cambridge : Harvard University Press.

DIK S.C, KOOIJ J.G. (1994). Ilmu Bahasa Umum. Belanda : Universitas Leiden. Jakarta : Departemen Pendidikan dan Kebudayaan.

Francis, w. Nelson. (1958). The Structure of American English Grammar. New York : The Ronald press.

Gleason Jr. , H.A. (1961). An Introduction To Descriptive Linguistics. New York : Rinehart and Winston, Inc.

Hocket, Charles F. (1961). A Course in Modern Linguistics. New York : The Macmilan Company.

Hornby, A. S. (1984). Oxford Advanced Learner's Dictionary of Current English. $13^{\text {th }}$ Edition. Oxford : Oxford University Press.

Ibrahim. (1987). Model Linguistik Dewasa Ini.Surabaya : Usaha Nasional.

Jones, Daniel. (1975). An Outline Of Phonetics. Cambridge : University Press.

Muslich, Masnur. (1985) Tata Bntuk Bahasa Indonesia. Malang : IKIP MALANG.

Ramelan. (1985). English Phonetics. Semarang : IKIP Semarang Press.

Samsuri. (1994). Analisis Bahasa. Jakarta : Erlangga.

Sudaryanto. (1985). Linguistik. Yogyakarta: Universitas Gajah Mada.

Tirtawijaya, Totong. (1987). Morfologi Bahasa Indonesia. Surabaya : IKIP Surabaya.

Verhear, WM. (1977).Pengantar Linguistik. Yogyakarta : Unuversitas Gajah Mada. 
Wong Hey Kee, Francis. (1973). Comparative Studies in Shouteast Asian Education. Hongkong : Heineman Education Books (Asia) Ltd.

Yule, George. (1985). The Study Of Language An Introduction. Cambridge : Cambridge University Press. 